\title{
Harvey, by Hercules! The Hero of the Blood's Circulation
}

\author{
MARJORIE O'ROURKE BOYLE* \\ 95 Normandy Boulevard, Toronto, Ontario, Canada M4L 3K4
}

\begin{abstract}
This article continues the analyses in Medical History 52 (2008), 73-90, 365-86 of William Harvey's self-understanding as the philosopher and discoverer of the blood's circulation. Harvey brilliantly and subversively assumed the persona of the mythological Hercules to embody his own anatomical labour in De motu cordis et sanguinis (1628). He reprised the role in self-defence against accusations in the College of Physicians, London, of his breach of faith with medical tradition. Harvey sought to usurp the medical epithet 'a second Hercules' by reforming humanist dependence on ancient texts as authoritative medicine. A knowledge of the theory and practice of Renaissance humanism discloses his identification with the Herculean labour of cleansing the Augean stable. He employed anatomical demonstration against Galen's porous cardiac septum, which admitted blood across the ventricles. Harvey's oath mehercule swore against Galen's Dia to assert the necessity of opening an alternate route for the blood flow. His Herculean labour was to dam the cardiac septum and divert the blood flow into a continuous channel through the arteries and veins. His circulation of the blood also imitated Hercules' successful dependence on the force of the water flow to flush the Augean stable. Harvey's copia did not denote a quantitative amount but a powerful supply. Harvey aspired to be, like Hercules, immortal, a term which the College belatedly acknowledged. This cultural analysis exposes Harvey's professional issues and personal ambitions, so to promote a fuller understanding of his historic role in medical discovery.
\end{abstract}

Keywords: William Harvey, Blood, Circulation of; Septum, Hercules, Augean Stables, Swearing

The virile oath mehercule exceeded the discipline of William Harvey's masterful Exercitatio anatomica de motu cordis et sanguinis in animalibus [An anatomical exercise on the movement of the heart and the blood in animals] (1628). ${ }^{1}$ Medical texts were not in the habit of swearing. Where they did swear - by Hercules, and by Zeus or Jove - marked the arguments Harvey swore in his ambition to alter the history of medicine from

\footnotetext{
*Email address for correspondence: mor.boyle@utoronto.ca

${ }^{1}$ William Harvey, Exercitatio anatomica de motu cordis et sanguinis in animalibus, facsimile reprint of Frankfurt: William Fitzer, 1628 (Birmingham, AL: Classics of Medicine Library, 1978), 18. Translations of Harvey's texts are mine, except as noted.
} 
tradition to science. ${ }^{2}$ Although the exclamation has been credited as 'colourful prose', 3 most English translations have avoided its literal sense. Renditions have been 'by my troth', 'in fact', 'in faith', 'damn it', 'damme, and 'in God's truth'. ${ }^{4}$ A single editorial revision told the truth, 'by Hercules'. 'The translator commissioned by the Royal College of Physicians for the tercentenary version rehearsed previous efforts, then explained his own expletive. "It took me two hours to think of "damme" as a sufficiently dramatic translation of "mehercule", but the Oxford English Dictionary then assured me that in the form "Damn me" it was in use as early as 1645, and I felt that the two hours had been well spent in getting the effect that Harvey had, to my mind, intended by his use of a particular Latin word'. 6 Yet the synonym for mehercule in good Renaissance English was 'by George', for the dragon slayer and national saint. ${ }^{7}$ Harvey chose the anachronism deliberately. His rhetoric displayed his personal character and professional end, as he brilliantly but subversively assumed the persona of Hercules to embody his own labours.

\section{Oaths}

Hercules was the classical superman, and masculine swearing by him was commonplace in classical culture. Among texts Harvey studied, Quintilian's Institutio oratoria, which governed the English curriculum, swore 'by Hercules' ${ }^{8}$ Cicero's oratory, which Harvey read in the sixth form at the King's School, Canterbury, ${ }^{9}$ swore mightily 'by Hercules', from familiar letters to forensic practice. ${ }^{10}$ Harvey learned to speak Latin from Terence's comedies, which boasted ninety-six oaths hercle (mehercle twice). A dozen were in

\footnotetext{
2 See Marjorie O'Rourke Boyle, 'William Harvey's Anatomy Book and Literary Culture', Medical History, 52 (2008), 73-90; 'Reprising Terence's Plot: William Harvey's Soliloquy to the College of Physicians', Medical History, 52 (2008), 365-86; 'Harvey in the Sluice: From Hydraulic Engineering to Human Physiology', History and Technology, 24 (2008), 1-23.

${ }^{3}$ Donald Proctor, 'William Harvey (1578-1657): Blood Circulates', in Donald Proctor (ed.), A History of Breathing Physiology (New York: Marvel Dekker, 1995), 61-74: 69.

${ }^{4}$ Anonymous (trans.), The Anatomical Exercises of Dr William Harvey 'De motu cordis' 1628: 'De circulatione sanguinis' 1652: The First English Text of 1653, Geoffrey Keynes (ed.) (London: Nonesuch, 1928), reprinted in part two of op. cit. (note 1), 13; Michael Ryan (trans.), 'The Anatomical Exercitations of William Harvey MD’, London Medical and Surgical Journal 1 (1832), 590-94: 591; Robert Willis (trans.), The Works of William Harvey, MD (London: Sydenham Society, 1847), 17; Chauncey D. Leake (trans.), Exercitatio anatomica de motu cordis et sanguinis (Springfield, IL: Charles C. Thomas, 1931), 21; Kenneth J. Franklin (trans.), Movement of the Heart and Blood in Animals (Oxford: Blackwell Scientific for the Royal College of Physicians of London, 1957), 19; Gweneth Whitteridge (trans.), An Anatomical Disputation Concerning the Movement of the Heart and Blood in Living Creatures by William Harvey (Oxford: Blackwell Scientific, 1978), 20; Emerson T. McMullen (trans.), William Harvey's 'De motu cordis': A New Translation and Latin Edition (Bethesda, MD: Academica, 2005), 115 .

${ }^{5}$ Alexander Bowie (London: George Bell and Sons, 1889), 18. Cf. An Anatomical Dissertation upon the Movement of the Heart and Blood in Animals Being a Statement of the Discovery of the Circulation of the Blood; Facsimile Reprint of Frankfurt 1628 with a Translation and Memoir (Canterbury: G. Moreton, 1894), 17. Although no translator is credited, the memoir is signed 'B' likely for Bowie. Cf. only 'pores' for 'porosities'.

${ }^{6}$ Kenneth J. Franklin, 'On Translating Harvey', Journal of the History of Medicine, 12 (1957), 17-18.

${ }^{7}$ For George, see Robert Graves, 'Lars porsena', or the Future of Swearing and Improper Language, 2nd edn (London: Kegan Paul, Trench, Treubner, 1936), 8-9; Ashley Montagu, The Anatomy of Swearing (New York: Macmillan, 1967), 117.

${ }^{8}$ Quintilian, Institutio oratoria 1.4.7, 2.5.4, 2.16.12, 6.1.43, 6.3.74, 10.2.3, 12.1.7, 12.6.4. For his supremacy in the English curriculum, see Thomas W. Baldwin, William Shakespere's Small Latine and Lesse Greeke, 2 vols (Urbana, IL: University of Illinois Press, 1944), Vol. 2: 197-238.

9 'Cathedrals of the New Foundation, 1541', in Arthur F. Leach, Educational Charters and Documents, 598-1909 (Cambridge: Cambridge University Press, 1911), 468.

${ }^{10}$ Charleton T. Lewis and Charles Short, A Latin Dictionary (Oxford: Clarendon Press, 1969), s.v. 'Hercules'.
} 
Adelphi, the play Harvey soliloquised to the College of Physicans, London, about his role as the discoverer of the blood's circulation. ${ }^{11}$ Harvey's mehercule was not colour but argument. Renaissance rhetoric invented arguments by imitation, best by emulation, which transcended the style of masters by cultivating a native gift. ${ }^{12}$ Writers of genius reprised traditional roles to discover and display their own identity. ${ }^{13}$ As an emulator, Harvey echoed but parodied oaths in medical masterpieces to assert his own anatomical convictions. Despite his characterisation as 'very Cholerique' and 'hott-headed', his mehercule was not verbal swashbuckling like his youthful fashion of wearing and drawing a dagger. ${ }^{14}$ Although choler was blamed for swearing, ${ }^{15}$ Harvey's oath was not a temperamental outburst. An oath was often reinforced by certe or certo, 'for certain', as a marker of truth. ${ }^{16}$ The oath mehercule stated truth and elicited assent, as in Plautus's line, 'By Hercules, you really speak correctly, and I agree with you'. ${ }^{17}$ On the London stage, a soldier in William Shakespeare's Antony and Cleopatra freely swore 'by Hercules, I think I am i' th' right'. 18

Harvey's serious purpose in swearing to his colleagues 'by Hercules' was signalled by his prior oath, Deus bone. All translations have rendered it faithfully as 'Good God!' although none has commented on its oddity in an anatomy book. ${ }^{19}$ The excuse of 'exasperation' 20 diminished its import. Swearing was common enough in Harvey's society. It encompassed 'the calling to witness of something, divine or otherwise, to seal vows of allegiance and promises of love or to attest the truth of a statement; and the inclusion of a similar phrase in a more exclamatory fashion to add emphasis to one's speech'. ${ }^{21}$ Swearing was a political necessity to secure civil authority and order, especially once Henry VIII's breach with Rome necessitated the Oath of Succession. That reform then required of subjects successive oaths of loyalty to the monarchy, disloyalty to the

11 'Hercle', 'mehercle', in Lexicon Terentianum, Patrick McGlynn (ed.), 2 vols (London: Blackie and Son, 1963), Vol. 1:231-2, 454-5. See also Frank W. Nicholson, 'The Use of hercle (mehercule), edepol (pol), Ecastor by Platus and Terence', Harvard Studies in Classical Philology, 4 (1893), 99-103. Harvey, op. cit. (note 1), 21.

12 Thomas M. Greene, The Light in Troy: Imitation and Discovery in Renaissance Poetry (New Haven, CT: Yale University Press, 1982); George W. Pigman III, 'Versions of Imitation in the Renaissance', Renaissance Quarterly, 33 (1980), 1-32; Jo Ann Della Neva, 'Reflecting Lesser Lights: The Imitation of Minor Writers in the Renaissance', Renaissance Quarterly, 42 (1989), 449-79.

13 See e.g. Charles Trinkaus, The Poet as Philosopher: Petrarch and the Formation of Renaissance Consciousness (New Haven, CT: Yale University Press, 1979), 9, 23-4; Stephen Greenblatt, Renaissance SelfFashioning: From More to Shakespeare (Chicago, IL: University of Chicago Press, 1980), 1-9, 256-7.

14 John Aubrey, 'Account of William Harvey', Appendix I in Geoffrey Keynes, The Life of William Harvey (Oxford: Clarendon, 1966), 434, 435. Cited by Franklin, op. cit. (note 6), 17-18.

15 Frances A. Shirley, Swearing and Perjury in Shakespeare's Plays (London: George Allen and Unwin, 1979), 12.

${ }^{16}$ Montagu, op. cit. (note 7), 31-2.

${ }^{17}$ Plautus, Mercator line 411.

18 Shirley, op. cit. (note 15), 2; Geoffrey Hughes, Swearing: A Social History of Foul Language, Oaths, and Profanity in English (Oxford: Blackwell, 1991), 104. Shakespeare, Antony and Cleopatra III.vii.67. For that play as Herculean, see Eugene M. Waith, The Herculean Hero in Marlowe, Chapman, Shakespeare, and Dryden (London: Chatto and Windus, 1962), 113-41. For pagan oaths in Shakespeare's classical plays, see Shirley, op. cit. (note. 15), 126-33. For Shakespeare's use of Hercules, see Adrian Poole, review of Charles Martindale and A.B. Taylor (eds), Shakespeare and the Classics, in the The Times Literary Supplement, 29 July 2005, 10.

${ }^{19}$ Harvey, op. cit. (note 1), 6; Anonymous (trans.), op. cit. (note 4), 11; Ryan (trans.), op. cit. (note 4), 591; Willis (trans.), op. cit. (note 4), 16; Bowie (trans.), op. cit. (note 4), 16; Leake (trans.), op. cit. (note 4), 18; Franklin (trans.), op. cit. (note 4), 17; Whitteridge (trans.), op. cit. (note 4), 18; McMullen (trans.), op. cit. (note 4), 113.

${ }^{20}$ Roger French, William Harvey's Natural Philosophy (Cambridge: Cambridge University Press, 1994), 99.

${ }^{21}$ Shirley, op. cit. (note 15), xi. 
papacy and other foreign powers. ${ }^{22}$ The parliamentary Act of Supremacy required the oath of fealty thus: 'I, name, do utterly testify and declare in my conscience.... So help me God and by the contents of this Book'. ${ }^{23}$ Although in Harvey's days at the University of Cambridge that oath was not enforced among candidates for the bachelor of arts, ${ }^{24}$ later in 1605 he was obliged to take the prescribed Oath of Allegiance to James I. The law specified 'all doctors of physick, and all others who practice physick, that now are or hereafter shall be admitted into the College of Physicians in London' ${ }^{25}$ Harvey did so 'trewly and sincerely acknowledge, professe, testifie, and declare in my conscience before God and the world.... And I do make this Recognition and acknowledgment heartily, willingly, and trewly, vpon the trew faith of a Christian. So helpe me GOD' ${ }^{26} \mathrm{He}$ was further sworn to the king in 1618 as his physician extraordinary. ${ }^{27}$ That oath was taken on the King James Bible, with its freshly Englished commandment, 'Thou shalt not take the name of the Lord thy God in vain; for the Lord will not hold him guiltless that taketh his name in vain'. 28

Yet oaths were also sworn liberally and loosely in his contemporary England, not only by tinkers but also by gentlemen and those who aspired to their class by parroting their language. The unexpurgated plays of Shakespeare, whose death in April 1616 coincided with Harvey's inaugural Lumleian lecture in anatomy, were explosive with swearing and forswearing, grave and glib. Those dramatic oaths authenticated characters and moved plots. Since pagan oaths in drama were not subject to the censor, the allowance sharply increased resort to pagan deities. Moralists railed in pulpit and press against a populace who swore habitually, from sacred truths 'by God' to silly things 'by the mousefoot'. A canonical sin, subject to punishment in the ecclesiastical courts, in 1606, under Puritan pressure, profanity became a statutory crime in public performances and printed texts, subject to a fine of ten pounds. The law was extended in 1623 to general usage, subject to a shilling fine for the relief of the poor or three hours in the stocks. In 1627 the act was ratified by the parliament of Charles $\mathrm{I}^{29}$ to which king Harvey a year later dedicated $D e$ motu cordis et sanguinis. ${ }^{30}$ Harvey was liable to criminal charge for his oath Deus bone. Because his book was published abroad, by William Fitzer in Frankfurt, it escaped scrutiny by the newly appointed archbishop of London, William Laud, who licensed medical books

\footnotetext{
22 William Kerrigan, Shakespeare's Promises (Baltimore, MD: The Johns Hopkins University Press, 1999), $28-40$.

${ }^{23}$ See J.R. Tanner, Tudor Constitutional Documents, AD 1485-1603 (Cambridge: Cambridge University Press, 1922), 134.

${ }^{24}$ Mark H. Curtis, Oxford and Cambridge in Transition, 1558-1642: An Essay on Changing Relations between the English Universities and English Society (Oxford: Claredon, 1959), 171-2, 194, cf. 51.

${ }^{25}$ See George N. Clark, A History of the Royal College of Physicians of London, Vol. 1 (Oxford: Clarendon for the Royal College of Physicians, 1964), 191-2.

26 James I, The Political Works of James I, Charles H. McIlwain (ed.) (Cambridge, MA: Harvard University Press, 1918), 73-4. See also Lori Anne Ferrell, Government by Polemic: James I, the King's Preachers, and the Rhetorics of Conformity, 1603-1625 (Stanford, CA: Stanford University Press, 1998), 22-3, 133-6; Michael C. Questier, Conversion, Politics, and Religion in England (Cambridge: Cambridge University Press, 1996), 106-7.

${ }^{27}$ Keynes, op. cit. (note 14), 137.

${ }^{28}$ Ex. 20: 7 (AV).

${ }^{29}$ See in general Montagu, op. cit. (note 7), 107-72; Hughes, op. cit. (note 18), 55-125. See in particular Shirley, op. cit. (note 15), xii, xiii, 4-5, 7-10, and passim; Kerrigan, op. cit. (note 22); Montagu, ibid, 138-53, 157, 159, 163-4; Hughes, op. cit. (note 18), 103, 105, 108; Alvin B. Kernan, Shakespeare, the King's Playwright: Theater in the Stuart Court, 1603-1613 (New Haven, CT: Yale University Press, 1995), 14-16.

${ }^{30}$ Harvey, op. cit. (note 1), 3-4.
} 
and also excised or softened swearing in print. ${ }^{31}$ Nor did its dedicatee, Charles I, censure Harvey for his oath Deus bone, despite the king's pious reputation. Charles was esteemed 'so severe an exactor of gravity and reverence in all mention of religion... that he could never endure any light or profane word' ${ }^{32}$ His orthodoxy would be manifest when he imposed the et cetera oath, binding all doctors of physick to the established doctrine, discipline, and government of the Church of England. ${ }^{33}$ If Charles read Harvey's proem, the oath Deus bone did not deter the king from promoting him in 1631 his physicianin-ordinary. ${ }^{34}$ Although Harvey's mehercule may have been negligible, its first English translation in 1653, 'by my troth', was strictly unlawful. In 1635 letters patent established a public department to enforce in each parish the laws against swearing. In 1640 the parliamentary acts of 1623 and 1627 against swearing were also ratified. On the records, one Thomas Buttand was punished for uttering 'on my troth', ${ }^{35}$ so that Harvey's written 'by my troth' was spared notably.

The president of the College of Physicians, John Argent, to whom Harvey also dedicated his volume, ${ }^{36}$ could not have missed the oaths. Although the College was not legally empowered to censor books, it adjudicated not only malpractice but also comportment. ${ }^{37}$ Improper language was denounced and punished. Among its prosecutions of surgeons that Harvey attended were hearings against John Lumkin, who was imprisoned with a fine of twenty pounds for his 'abusive language, which was not to be borne', and William Kellet for his 'vile language', as 'contrary to the ordinance and good government of this house'. ${ }^{38}$ English physicians commonly swore lawfully, however. They took the ancient Hippocratic Oath 'by Apollo, Physician, by Asclepius, by Health, by Panacea and by all the gods and goddesses, making them my witnesses'. ${ }^{39}$ Their College, of which Harvey was a fellow, was a sworn society. Its statutes required an applicant's oath of his nationality,

${ }^{31}$ See Douglas Bush, English Literature in the Earlier Seventeenth Century: 1600-1660, 2nd edn rev. (Oxford: Clarendon, 1962), 27-8.

32 Edward Hyde, History of the Rebellion, W. Dunn Macray (ed.), 6 vols (Oxford: Clarendon, 1888), Vol. 4: 489, cited by Julian Davies, The Caroline Captivity of the Church: Charles I and the Remoulding of Anglicanism 1625-1641 (Oxford: Clarendon, 1992), 82.

33 Ibid., 82, 275-87. For religion, see also 5-45, 275-402; Kevin Sharpe, The Personal Rule of Charles I (New Haven, CT: Yale University Press, 1992), 280-2; L.J. Reeve, Charles I and the Road to Personal Rule (Cambridge: Cambridge University Press, 1989), 59-98.

${ }^{34}$ For the appointment, see Keynes, op. cit. (note 14), 279.

35 Montagu, op. cit. (note 7), 166-7, cf. 118; Shirley, op. cit. (note 15), 9. Oxford English Dictionary, 2nd unabridged edn, s.v. 'troth'.

${ }^{36}$ Harvey, op. cit. (note 1), 5-9.

${ }^{37}$ See Clark, op. cit. (note 25), 93, 188-90. For Harvey as a censor, see 293; Charles Webster, 'William Harvey and the Crisis of Medicine in Jacobean England', in Jerome J. Bylebyl (ed.), William Harvey and His Age: The Professional and Social Context of the Discovery of the Circulation (Baltimore, MD: The Johns Hopkins University Press, 1979), 7-8.

38 Keynes, op. cit. (note 14), 63, 65.

39 'The Oath', in Hippocrates, W.H.S. Jones (trans.), 2 vols (London: William Heinemann, 1923), Vol. 1: 299. For the swearing, see Heinrich von Staden, "In a Pure and Holy Way”: Personal and Professional Conduct in the Hippocratic Oath?', Journal of the History of Medicine and Allied Sciences, 51 (1996), 404-37: 409; Charles Lichthenthaeler, Der Eid des Hippokrates: Ursprung und Bedeutung (Cologne: Deutscher Ärzte, 1984), 41-8; Leon Edelstein, The Hippocratic 'Oath': Text, Translation, and Interpretation (Baltimore, MD: The Johns Hopkins University Press, 1943), 50; Steven H. Miles, The Hippocratic 'Oath' and the Ethics of Medicine (Oxford: Oxford University Press, 2004), 14, 159-64. For Renaissance texts and translations, see Thomas Rütten, 'François Tissard and his 1508 edition of the Hippocratic Oath', in Philip J. van der Eijk (ed.), Hippocrates in Context (Leiden: Brill, 2005), 465-91; Thomas Rütten, 'Receptions of the Hippocratic Oath in the Renaissance: The Prohibition of Abortion as a Case Study in Reception', Leonie von Reppert-Bismark (trans.), Journal of the History of Medicine and Allied Sciences, 51 (1996), 456-68. 
his collegiate duties such as the aid or avoidance of fellows, certain Hippocratic ethics, attendance at anatomical demonstrations, and the reading of stipulated works of Galen. Its statutes also required oaths upon the admission of an officer, which Harvey became, and the passage of statutes, whose revision he assisted. Breach of oath was subject to a fine under penalty of expulsion. The College even summoned under seal the excluded - apothecaries, surgeons, druggists, nurses, and servants of patients - to testify to its president and censors under oath. It had petitioned the king for the right to administer oaths to external witnesses 'lest Medicine perish'. ${ }^{40}$ Its annals recorded Harvey in 1604 taking the oath as a licentiate 'according to the form in the Statutes' ${ }^{41}$ His further solemn charge in 1609 as physician to the sick poor at St Bartholomew's Hospital, London, twice enjoined the performance of his duties 'in God his most holly name'. ${ }^{42}$

Swearing vainly by God's name was sin against the third biblical commandment, which he learned as a requirement for his admission as a boy to the King's School. ${ }^{43}$ In his Prelectiones anatomie universalis [Lectures of the whole anatomy], Harvey repudiated swearing even by one's head. Regarding the philosophical dispute about the seat of the soul, he considered the head the perfect part whereby humans excelled and dominated. 'Whence the head is the most precious member, and to swear by the head and waste the holy is sinful'. ${ }^{44}$ As the manual that set the style for English behaviour, Henry Peacham's The Compleat Gentleman, advised, 'But aboue all, in your talke and discourse haue a care euer to speake the truth, remembering that there is nothing that can more preiudice your esteeme then to be lauish-tongued in speaking that which is false'. He noted that Plato allowed only physicians to lie, and that only for the comfort of the sick. ${ }^{45}$ Harvey's oaths in De motu cordis et sanguinis swore not vainly but truthfully, not blasphemously but legitimately.

Profanity, the invocation of God or gods to witness the truth, was an ancient type of judicial oath administered by social bodies for protection from lying individuals. ${ }^{46}$ Not all Protestant reformers were as incensed about swearing as the Puritans and Anabaptists. Calvin, whose theology dominated the Church of England, ${ }^{47}$ decried its promiscuity but retained its legitimacy. As a lawyer turned theologian, he justified not only public oaths, such as swearing fealty to a monarch, but also private oaths taken 'soberly, solemnly, reverently in necessary matters'. ${ }^{48}$ His magisterial Institutio christianae religionis argued a case that fit Harvey's contested situation in the College as its lecturer in anatomy. Some

${ }^{40}$ Clark, op. cit. (note 25), 101, 177, 221, 222, 93, 94, 231, 213.

${ }^{41}$ Annals of the Royal College of Physician, 1518-1915, 48 vols (London: The College, 1518-1915), Vol. 2: 179a. For the Statuta vetera, see Clark, op. cit. (note 25), 172-81.

42 See Keynes, op. cit. (note 14), 53-4.

43 'The Refoundation of Canterbury Cathedral and Grammar School, 1541', in Leach, op. cit. (note 9), 464.

${ }^{44}$ William Harvey, The Anatomical Lectures of William Harvey: 'Prelectiones anatomie universalis', 'De musculis', Gweneth Whitteridge (ed.) (Edinburgh: E. \& S. Livingstone for the Royal College of Physicians, London, 1964), 310. Translations are mine. For bodily oaths, see also Montagu, op. cit. (note 7), 63, 118; Shirley, op. cit. (note 15), 20. For the Ciceronian curse 'On their own heads be it!', see Erasmus, De copia verborum ac rerum, Betty I. Knott (ed.), in Opera omnia (Amsterdam: North-Holland, 1971-), Vol. 1-6: 416 (hereafter Amsterdam); Betty I. Knott (trans.), The Collected Works of Erasmus (Toronto: University of Toronto Press, 1974-), Vol. 24: 494 (hereafter Collected Works of Erasmus). Cf. Matt. 5: 36.

${ }^{45}$ Henry Peacham, The Complete Gentleman, the Truth of Our Times, and the Art of Living, Virgil B. Heltzel (ed.) (Ithaca, NY: Cornell University Press for the Folger Shakespeare Library, 1962), 158-9.

${ }^{46}$ Montagu, op. cit. (note 7), 59-61.

${ }^{47}$ G. Lake, 'Calvinism and the English Church, 1570-1635', Past and Present, 114 (1987), 32-76: 34.

48 John Calvin, Institutio religionis christianae, in Eduard Reuss et al. (eds), Opera quae supersunt omnia, 59 vols in 26 (Brunswick: C.A. Schwetschke, 1863-1900), Vol. 2: col. 286. 
fellows, Harvey complained in his proem, falsely accused him of a breach of faith with medical precepts. ${ }^{49}$ Fellows were sworn against 'speaking ill of fellows', and accusing a colleague was subject to fine for the first offense, fine and expulsion for the second. Harvey had twice served as a censor, so he knew the statutes permitted the investigation of slander. ${ }^{50} \mathrm{He}$ reported a consensus that he was slandering Galen's medicine, thus Galen's faithful. That accusation provoked his self-defence sealed by those oaths. As justification, Calvin had reasoned from scripture that if it is lawful in grave and serious matters for individuals to call God to judge between them, much more so is it lawful to call him as a witness'. Suppose, he wrote, your brother accuses you of perfidy, and in charitable duty you strive to clear yourself, but no reasoning satisfies him. Then, Calvin argued, 'if public opinion of you becomes divided because of his obstinate illwill, without offense you may call forth the judgement of God so that in time your innocence may be manifest'. The underside of the invocation of divine authority involved a curse upon false or frivolous words. As Calvin explained, 'We cannot avail ourselves of God as the witness of our speech without imprecating him as the punisher of our perjury, should we deceive'. ${ }^{51}$ Harvey's swearing was asseveration, or solemn affirmation, entailing adjuration, a potential curse upon himself for falsehood. ${ }^{52}$ The Hippocratic Oath ended in such an imprecation on its violation by transgression or perjury. 'Now if I carry out this oath, and break it not, may I gain for ever reputation among all men for my life and for my art; but if I transgress it and forswear myself, may the opposite befall me'. ${ }^{53}$

Both of Harvey's oaths occurred in his proem, the rhetorical statement of purpose. ${ }^{54}$ Both oaths strategically concluded paragraphs condemning the Galenic cardiovascular tradition, to which the College adhered. Harvey swore in order to reject Galen's fundamental belief in the universal power of physical attraction. Galen swore Dia, 'by Zeus!', precisely to explain the attractive faculties of the heart and the arteries in the blood flow. ${ }^{55}$ Harvey invoked Deus bone to witness to the falsehood of Galen's system of the exchange of air and spiritous blood between the lungs and heart. 'Good God! How do the tricuspid clacks impede the egress of air and not of blood?' 56 By swearing his objection to Galen's physiology, Harvey elevated his own from reasonable thought to a matter of conscience. His charge to care for the patients at St Bartholomew's Hospital 'in God's most holly name' became a mission in the College of Physicians to correct the principal error of traditional medicine. For that is how Harvey regarded the heart, as the principium, analogous to the king as the principium. ${ }^{57}$

\footnotetext{
${ }^{49}$ Harvey, op. cit. (note 1), 21.

${ }^{50}$ See Clark, op. cit. (note 25), 177, 181, 293, 190.

51 Calvin, op. cit. (note 48), 287, 284.

52 For the terms, see Montagu, op. cit. (note 7), 105.

${ }^{53}$ Hippocratic corpus, op. cit. (note 39), 300; (trans.), 301. See Sanford V. Larkey, 'The Hippocratic Oath in Elizabethan England', Bulletin of the History of Medicine, 4 (1936), 201-19: 215, 217, 219. See also Miles, op. cit. (note 39), 163-4.

54 Aristotle, Rhetorica 3.14.6.

55 Galen, 'De facultatibus naturalibus', in Karl Gottlob Kuhn (ed.), Opera, 22 vols in 20 (Leipzig: Cnobloch, 1821-31), Vol. 2: 202. For attraction, see Thomas S. Hall, 'Euripus; or, the Ebb and Flow of the Blood', Journal of the History of Biology, 8 (1975), 324-31. Cf. the oath 'per Iovem' about the failure of anatomists to dissect humans. Vesalius, De humani corporis fabrica (Basel: I. Oporini, 1543), 3r.

56 Harvey, op. cit. (note 1), 16.

57 Ibid., 42, 59. Cf. Harvey, op. cit. (note 44), 2, citing Virgil, Eclogiae 3.60. See also Erasmus, De ratione studii, Jean-Claude Margolin (ed.), in Opera omnia (Amsterdam), Vol. 1-2: 139-42.
} 
His pagan oath, mehercule, extended his repudiation of the cardiovascular tradition. Harvey's mehercule sworn in his prooemium paralleled Celsus's Hercules sworn in his prooemium of the basic Roman medical text. ${ }^{58}$ With better latinity, Harvey invoked Hercules in the vocative case and with the preferred Ciceronian usage, mehercule. ${ }^{59}$ Celsus's review of the medical schools swore, 'By Hercules, the ancient doctors were not ignorant of that'. He referred to their diagnostic consideration of the commonalities of diseases, following upon an example of professional interest to Harvey. 'Those who take charge of large hospitals, because they cannot pay full attention to individuals, resort to these common characteristics' ${ }^{60}$ With his own oath, Harvey dismissed Celsus's assertion of ancient medical knowledge, with 'by Hercules', the ancients were an ignorant lot! The insinuation, couched in an oath, was thematic of Harvey's proem, which confronted tradition with innovation. The quarrel of the ancients and the moderns, which characterised the Renaissance revival of classical learning against medieval 'barbarism', was transferred from literature to medicine - but with reverse valuation. The humanist recourse to correct texts, rather than demonstrated anatomies, Harvey believed had ultimately deterred the advancement of medical knowledge. Harvey's modern method intended to undo classical opinion. But he ingeniously employed classical texts to justify that subversion.

\section{Labours}

Harvey impersonated the demigod Hercules by whom he swore the truth. Herakles/ Hercules was the outsized hero of classical legends whose mutable literary fortune elastically encompassed the tragic and comic, virtuous and vitious, intellectual and physical. ${ }^{61}$ His huge character was imitated by protagonists of Marlowe and Shakespeare who strutted the London stages for edification and entertainment. ${ }^{62}$ Of Hercules' literary successors, Vergil's epic hero, Aeneas, was the outstanding role model for Harvey as royal physician and collegiate anatomist. Vergil intended his Herculean heroism to deify the emperor Caesar Augustus for his political labours. Through the influence of euhemerism, which transfigured the classical pantheon into men elevated to gods by their devout descendents, the ideology strongly impressed Renaissance culture. ${ }^{63}$ Harvey's epistle dedicatory to his patron Charles I was not simple courtesy. Hercules was since antiquity a model of the ethical ideal king. ${ }^{64}$ European royal households claimed descent from Hercules for a legitimacy and authority derived from his essential virtue of fortitude in intense suffering against all odds. ${ }^{65}$ Henry Prince of Wales, the eldest son of James I, was invested with the persona of Hercules from his Scottish Presbyterian baptism. The babe

${ }^{58}$ Celsus, De medicina prooem. 66.

${ }^{59}$ Cicero, Orator 157.

${ }^{60}$ Celsus, op. cit. (note 58) 66; first trans. mine; second, W.G. Spencer (trans.), 3 vols (Cambridge, MA: Harvard University Press, 1971-9), Vol. 1: 35.

${ }^{61}$ G. Karl Galinsky, The Herakles Theme: The Adaptations of the Hero in Literature from Homer to the Twentieth Centuty (Oxford: Basil Blackwell, 1972).

${ }^{62}$ Waith, op. cit. (note 18). Around the turn of the seventeenth century 'The Birth of Hercules' was performed at Cambridge. G.C. Moore Smith, College Plays Performed in the University of Cambridge (Cambridge: Cambridge University Press, 1923), 65.

63 Galinksy, op. cit. (note 61), 35, 128, 129, 131-47. See also 138-9.

${ }^{64}$ Ibid., 35. See also Marc-René Jung, Hercule dans la littérature française du XVIe siècle: De l'Hercule courtois à l'Hercule baroque (Geneva: Droz, 1966), 159-69, 174-7; Ulrich Huttner, Die politische Rolle der Heraklesgestalt im griechischen Herrschertum (Stuttgart: Franz Steiner, 1997).

65 Stephen Orgel, 'The Example of Hercules', in Walther Killy (ed.), Mythographie der frühen Neuzeit: ihre Anwendung in den Künsten (Wiesbaden: O. Harrassowitz, 1984), 25-47: 25, 27. 
was displayed on a bed of state decorated with a tapestry embroidered with the labours of Hercules, although his beasts to slay were Rome and Spain. ${ }^{66}$ At his death, his successor to the throne, Charles I, was celebrated by his courtiers as a new Caesar Augustus, a type of Hercules, ${ }^{67}$ as Vergil's Aeneid had poetised. Harvey's comparison of the heart, prince of the body, to Charles, prince of England, ${ }^{68}$ implied that whatever honour accrued to his anatomical labours would attach to the king. It suggested that De motu cordis et sanguinis would earn Charles greater fame than the books by royal physicians Harvey would best: Galen, his translators Thomas Linacre and John Caius, and Andreas Vesalius. In the end his patron suffered regicide, for which the Book of Common Prayer atoned. Its office for the fast day of Charles I, martyr, extolled his virtues. But his models were the biblical kings Josiah and David, and Christ in his divine passion ${ }^{69}$ - not Hercules in his heroic endurance.

Vergil's Aeneas as a second Hercules was an exemplar of filial piety, memorable in the flight from Troy, in which he carried his father on his shoulders. ${ }^{70}$ Harvey in his flight from tradition was not so pious. He paid what respects he could to his medical fathers; ultimately he unloaded them from his back. But that decision also imitated Hercules, who departed egregiously from social morality and its conventions. ${ }^{71}$ Hercules did not observe the classical ethic that expected everyone to maintain their stations in life and respect their superiors. ${ }^{72}$ Moreover, for his 'madness' in slaying his children, Hercules was diagnosed, since the medieval Pseudo-Aristotelian Problemata, as a melancholic. He became an Elizabethan type of temporary insanity as a frenzied actor or mad hero. Through Platonist spiritualisation of melancholy, he was associated with the ecstatic inspiration of geniuses. ${ }^{73}$ As a Hercules, Harvey could thus be acknowledged as a healing physician or mistaken for a delirious patient.

Harvey learned the Herculean legends as a boy from Erasmus's De duplici copia verborum et rerum, the statuory textbook for Latin rhetoric at the King's School. To instruct a full and fluent style, it advanced Hercules variously, as an example of an epithet from deeds, 'Hercules, reducer of monsters'; of variety by substitution, 'the man from Tiryns'; of similitude, 'a second Hercules'; of prosperity, the adage 'with Hercules' blessing'; of fictional example, 'the story of Hercules fighting the twin-horned Achelous'. The similitude 'a second Hercules' became Harvey's ambition. He learned under 'fictional examples' that 'the labours of Hercules tell us that immortal renown is won by effort and by helping others'. ${ }^{74}$ From Horace, also required reading, he learned that Hercules was 'the man tenacious of his purpose in a righteous cause', who earned the 'starry

\footnotetext{
66 Jerry W. Williamson, The Myth of the Conquerer, Prince Henry Stuart: A Study in Seventeenth Century Personation (New York: AMS, 1978), 1-4, 6, 7, 33, 75-6.

${ }^{67}$ Robert Wilcher, The Writing of Royalism, 1628-1660 (Cambridge: Cambridge University Press, 2001), 11, 13.

${ }^{68}$ Harvey, op. cit. (note 1), 3-4.

${ }^{69}$ Andrew Lacey, 'The Office for King Charles the Martyr in the Book of Common Prayer, 1662-1685', Journal of Ecclesiastical History, 53 (2002), 510-26: 510-14, 523-4.

70 Vergil, Aeneid 6.110-11.

71 See Waith, op. cit. (note 18), 11.

72 Galinsky, op. cit. (note 61), 6.

73 Rolf Soellner, 'The Madness of Hercules and the Elizabethans', Comparative Literature, 10 (1958), 309-24. Pseudo-Aristotle, Problemata 953a.

${ }^{74}$ Erasmus, op. cit. (note 44), 216, 60, 152, 180, 236; (trans.), 591, 331, 481, 538, 611. See also the eloquent Gallic Hercules, 206, 216; and Peacham, op. cit. (note 45), 18. For the curriculum, see Leach, op. cit. (note 9), 468.
} 
citadels' with the gods. ${ }^{75}$ Erasmus's De ratione studii, frequently printed with De copia, advised schoolmasters that topics for boys should not be empty and dull but instructive and delightful. It proposed the mythological example that 'Hercules won immortality for himself by vanquishing monsters'. Since it recommended for boys exercises based on fables, ${ }^{76}$ Harvey may well have practiced his Latin letters on storied Hercules.

The Renaissance exemplar of 'the labours of Hercules' was Erasmus himself. His Adagia, the massive collection of classical sayings that included it, impressed English culture, for the most striking feature of early seventeenth-century English speech was its proverbial habit. ${ }^{77}$ Erasmus's volume was researched in England, dedicated to an English patron, and concluded with a letter to Prince Henry (King Henry VIII) and a poem in praise of England. Enthusiastic readers there culled it for their compositions, and also translated, annotated, and incorporated it into native dictionaries. Copies were sold to individuals, from penurious scholars to wealthy collectors, who bequeathed them in their wills. College libraries shelved it. ${ }^{78}$ Adagia was in the basic curriculum. ${ }^{79}$ In his essay on the labours of Hercules' Erasmus explained one meaning as 'continuous and very great exertions, and as such as demand Herculean strength'. He promoted his own literature as surpassing the norm with 'much more than Herculean labours'. That definition coincided with Harvey's medical achievement. The other meaning of the adage fit Harvey's situation before his critics. Erasmus identified it as 'tasks of the kind that bring very great blessings to other people, but almost no return to the man who undertakes them, except a little reputation and a great deal of ill-will'. Harvey attributed his detractors' motive to individia, 'envy', a passion he diagnosed as pathogenic because it altered the heart and caused diseases. ${ }^{80}$ His blame echoed Erasmus's repeated equation of Hercules' labours with the provocation of invidia, 'envy'. Erasmus quoted Horace's epistle to Caesar Augustus on how Hercules learned at the end of his labours that the last monster to be vanquished was envy. ${ }^{81}$ In English experience, George Chapman compared his translation of the twice twelve books of Homer's Odyssey to the twelve labours of Hercules and complained of the envy the deed invited. ${ }^{82}$

But Harvey was not intent on the translation of Greek classics, even their medical texts. His oath 'by Hercules' desired to achieve by his anatomical demonstrations the immortality that mortal won for his heroic deeds. From his folkloric origin as a strong boy, Hercules embodied perfect physis, ${ }^{83}$ so that a doctor, practitioner of 'physicke,' was a credible successor. A Herculean role for a physician was classical, and a doctor could boast of being a descendent. In antiquity Hercules could be vowed a tithe of property in exchange

\footnotetext{
75 Horace, Odes 3.3.9-12; C.E. Bennett (trans.), The Odes and Epodes, rev. edn (Cambridge, MA: Harvard University Press, 1927), 179.

${ }^{76}$ Erasmus, op. cit. (note 37), 126; (trans.), 676, 131.

77 See Carl Bridenbaugh, Vexed and Troubled Englishmen: 1590-1642 (New York: Oxford University Press, 1968), 43.

${ }^{78}$ Erika Rummel, 'The Reception of Erasmus' Adages in Sixteenth-Century England', Renaissance and Reformation, 30 (1994), 19-25.

79 Baldwin, op. cit. (note 8), Vol. 2: 749.

${ }^{80}$ Harvey, op. cit. (note 1), 21, 59.

${ }^{81}$ Erasmus, 'Herculi labores', in M.L. van Poll-von de Lisdonk et al. (eds), Adagia, in Opera omnia (Amsterdam), Vol. 2-5: 24, 26, 28, 39. See also Galinsky, op. cit. (note 61), 139-41.

${ }^{82}$ George Chapman and Allardyce Nicoll (eds), Chapman's Homer: The 'Iliad', the 'Odyssey', and the Lesser Homerica, 2 vols (New York: Pantheon for the Bolligen Foundation, 1956), Vol. 2: 8, lines 203, 210.

${ }^{83}$ See Galinsky, op. cit. (note 61), 2-3, 102.
} 
for a healing, or erected a fountain in honour of the god more effective than doctors. ${ }^{84}$ The emperor and philosopher Marcus Aurelius swore his health 'by Hercules'. ${ }^{85}$ Although mythology did not associate Hercules and medicine, cult evidenced his role in healing. The association may have derived from his role as alexikakos, 'protector against evil', through the hard labours that witnessed to his endurance in suffering. Hercules became paralleled or conflated with Aesculapius, the god of medicine. A Herculean motif was prolific on classical surgical instruments: probe, retractor, grip, scalpel, handle, elevator, curette, strigil, and holder. Among the naturalistic designs, probably the most popular was the bark and knot of a tree limb or trunk to symbolise Hercules's club. Knife hafts were realistically shaped like Hercules's bust in his lion skin, and a retractor's finial copied the head of the Nemean lion he slew. A Herculean motif was most frequent on instruments that caused or alleviated pain. When surgeons gripped their Herculean knives, they sought to imitate his bold righting of wrong, while patients were reminded of his patience in danger and pain. ${ }^{86}$

A medical Hercules was prototypical in Hippocrates, father of medicine, who traced his ancestors to him. Pliny's Naturalis historia recorded Hippocrates' prescience of a 'plague' and dispatch of his disciples to attend it, 'for which service Greece voted him the honours that it gave to Hercules', initiation in the Eleusinian mysteries at public expense and Athenian citizenship. Hippocrates' legendary remedy for that Athenian 'plague' was a conflagration in the public streets to counteract airborne miasma. ${ }^{87}$ Harvey knew the report because in imitation therapeutic bonfires against plague were a regular practice in London's streets. ${ }^{88}$ Horror and duty weighed on him and those collegiate fellows summoned in 1625 by the lord mayor to confer with the aldermen toward a solution. ${ }^{89}$

While Harvey's aspiration to be 'a second Hercules' had an ancient predecessor in Hippocrates, it had a Renaissance pretender in England in Lupset. The preface to Galen's commentaries on Hippocrates in the first edition praised Linacre's translations and credited Lupset for editorial assistance. 'Nor should you belittle in this service Lupset, who exerted himself with every sinew', labouring like 'a second Hercules' ${ }^{90}$ In the mould of the humanist and physician, Lupset was a graduate of St Paul's School in London, of

\footnotetext{
${ }^{84}$ Vivian Nutton, Ancient Medicine (London: Routledge, 2004), 273, 290, 279, 35.

85 Marcus Aurelius, in Michel J. van den Hout (ed.), Marcus Cornelius Fronto, Epistulae, 2 vols (Pisa: Giardini, 1989), Vol. 1: 27; cf. 41, 75.

${ }^{86}$ Lawrence J. Bliquez, Roman Surgical Instruments and Other Minor Objects in the National Archeological Museum of Naples (Mainz: Philipp von Zabern, 1994), 99-106.

87 Jody R. Pinault, Hippocratic Lives and Legends (Leiden: E. J. Brill, 1992), 7-10, 25, 35-60, 41, 126, $145,147$. See also François Ratief and Louise Cilliers, 'The Epidemic of Athens, 430-426 BC', South African Medical Journal, 88 (1998), 50-3.

${ }^{88}$ See Charles F. Mullett, The Bubonic Plague and England: An Essay in the History of Preventative Medicine (Lexington, KY: University of Kentucky Press, 1956), 55, 64, 90, 125, 160, 164; Andrew Wear, Knowledge and Practice in English Medicine, 1550-1650 (Cambridge: Cambridge University Press, 2000), 231-2.

${ }^{89}$ See Webster, op. cit. (note 37), 3; Clark, op. cit. (note 25), 254-5.

${ }^{90}$ Prefaces to the First Editions of the Greek and Roman Classics and of the Sacred Scriptures, Beriah Botfield (ed.), (London: H. G. Bohn, 1861), 362, 364-65. Cf. Georg Agricola 'with Hercules blessing'. For dextro Hercule, see Erasmus, op. cit. (note 81), Vol. 2-1: 186. See Jonathan Woolfson, Padua and the Tudors: English Students in Italy, 1485-1603 (Toronto: University of Toronto Press, 1998), 80-5. See also Nikolaus Mani, 'Die griechische editio princeps des Galenos (1525), ihre Enstehung und ihre Wikung', Gesnerus, 13 (1956), 29-52; Paul Potter, 'The editiones principes of Galen and Hippocrates and Their Relation', in Klaus-Dieterich Fischer et al. (eds), Text and Tradition: Studies in Ancient Medicine and Its Transmission Presented to Jutta Kollesch (Leiden: E. J. Brill, 1998), 243-61. For the single detailed record of Linacre's medical practice, see Erasmus, P.S. Allen et al. (eds), Epistolae, 12 vols (Oxford: Clarendon, 1906-58), Vol. 6: 46-7; Alexander Dalzell (trans.), Collected Works of Erasmus, Vol. 11: 68. See also Francis Madison, 'Editor's Introduction',
} 
Cambridge University, and of Padua in medicine. He supervised the printing of Linacre's translations of Galen's De sanitate tuenda and De methodo medendi. ${ }^{91}$ The target for a Herculean club was overkill for English medicine, however, which was not very influenced by humanist methods. ${ }^{92}$

Harvey sought to usurp the epithet 'a second Hercules' by reforming humanist dependence on ancient texts as authoritative medicine. He would correct its misapplication, exemplified by that Greek edition of Galen and abetted by erudite translations of its errors. ${ }^{93}$ In Harvey's judgement, scholarship was dedicated to texts, rather than to medicine. Although its publications might promote understanding of traditional medicine, they certainly prolonged its errors. Humanism was not a subject but a method. Derived from the trivium, it favoured, against the hegemony of scholastic logic, the application of classical grammar to texts and classical rhetoric to arguments. ${ }^{94}$ Humanism as such did not endorse Galenism as medicine but as ancient literate argumentation superior to medieval barbaric reasoning. When Erasmus castigated the Aldine text of Galen as 'lies and sacrilege', ${ }^{95}$ he did not complain about its medicine but its manuscripts. As his commentary on the adage 'the labours of Hercules' explained, his humanist criticism concerned 'the prodigious corruption of the texts, which has acquired such a hold upon all our copies of both Latin and Greek authors that, whatever you touch in hopes of quoting it, you hardly ever have the good fortune not to stumble over some obvious error or suspect one below the surface'. Erasmus's solution was to encourage the acquisition and collation of more copies, ${ }^{96}$ not the requisition and dissection of more cadavers. His own translations of Galen were not of medical but propadeutic works, arts. Renaissance humanism commendably restored ancient medical texts that had been garbled in medieval transmission. But, for medicine, whose progress needed anatomical demonstrations above literary models, humanism was marginal. What medicine required, Harvey believed, was not critical editions of ancient texts but clinical investigations by modern anatomists. As he declared, he set his mind to 'observation', to invent the method for his own book 'from many dissections... through autopsies and not through the books and the writings of others'. ${ }^{97} \mathrm{He}$ accomplished that task as a practiced anatomist who could argue classical literature subversively against the propriety of humanism for medicine. ${ }^{98}$

Beyond the humanist Lupset as 'a second Hercules', there was another possessor of the title Harvey coveted. That was the celebrated anatomist Vesalius, whose De fabrica

in Madison et al. (eds), Linacre Studies: Essays on the Life and Work of Thomas Linacre, c. 1460-1524 (Oxford: Clarendon, 1977), xv-vi.

91 John A. Gee, The Life and Works of Thomas Lupset: With a Critical Text of the Original Treatises and the Letters (New Haven, CT: Yale University Press, 1928), 59-63, 117-18.

92 Charles D. O’Malley, English Medical Humanists: Thomas Linacre and John Caius (Lawrence, KS: University of Kansas Press, 1965), 18-19.

93 Erasmus (trans.), Galen, Exhortatio ad bonas artes praesertim medicinam, De optimo docendi genere, Et qualem oporteat esse medicum, Jan Hendrik Wasink (ed.), in Opera omnia (Amsterdam), 1-1: 629-69.

${ }^{94}$ See also Paul Oskar Kristeller, 'The Humanist Movement', in Michael Mooney (ed.), Renaissance Thought and Its Sources (New York: Columbia University Press, 1979), 21-32. For the term 'medical humanism', see recently Nancy G. Siraisi, History, Medicine, and the Traditions of Renaissance Learning (Ann Arbor, MI: University of Michigan Press, 2007), 4, 261-62.

95 Erasmus. op. cit. (note 93), 631-5.

96 Erasmus, op. cit. (note 31), Vol. 2-5: 29; Margaret Mann Phillips et al. (trans.), Collected Works of Erasmus, Vol. 34: 172.

97 Harvey, op. cit. (note 1), 20.

98 Boyle, op. cit. (note 2). 
corporis humani Harvey cited most often among modern authors. Vesalius's anatomy professor at the University of Paris, Johann Guinther of Andernach, praised his young prosector in his own anatomical textbook. Guinther swore about the discovery of the spermatic vessels by 'Andreas Vesalius, the son of the emperor's apothecary, by Hercules (me hercules) a youth of great promise, and extraordinary knowledge of medicine, also accomplished in both languages, and very dexterous in dissecting bodies...' That boast falsely credited his student with a discovery that other anatomists had published - Niccolò Massa in the same year, but previously Mondino dei Luzzi and Galen. ${ }^{99}$ Vesalius published an unauthorised emended edition of his professor's textbook to correct its typographical errors; but he did not correct that falsehood about himself. ${ }^{100}$ Vesalius knew the import of swearing the truth 'by Hercules'. In his Examen he confessed that, when he rent the substance of the veins to find the fibres, as Galen taught, and dissected the matter raw and cooked, 'by Hercules' (mehercule) the fibres were imaginary. ${ }^{101}$ Since Guinther's text was the first manual for anatomy students, Harvey knew its double and duplicit swearing 'by Hercules' on behalf of an alleged discovery. To restore integrity to anatomy, Harvey imitated Vesalius's oath 'by Hercules' on Galen's imaginary venous fibres with his own oath on Galen's imaginary porous septum.

Harvey confessed that, when he applied himself to understand the movement of the heart and the blood, from the very beginning he found it 'a matter quite arduous and immediately full of difficulties'. He only extricated himself 'from this labyrinth' by climbing up its steep slope and out. 'I got it', he finally wrote. ${ }^{102}$ How? by Hercules. Harvey's oath mehercule not only invoked that immortalised mortal to witness to the truth of his own arduous and difficult labours, it also intimated how Harvey invented about the blood's circulation. Or, rather, it indicated how Harvey chose to publicise that; for invention and disposition were distinct parts of argumentation. ${ }^{103}$ Hercules was legendarily ordered to atone for his mad slaying of his children by performing twelve mighty labours. Harvey identified his own anatomies as 'labours', ${ }^{104}$ and he imitated Hercules' labour of the cleansing of the Augean stable. In classical tales with various details, Augeas, king of Elis on the Greek mainland, kept a stable of three thousand oxen that had not been cleaned in thirty years. Hercules was assigned the formidable task of removing their dung in a single day. He mucked the Augean stable not with shovel, mop, or broom but by his wits. Noticing across from the stable the convenience of an adjacent river (or two), Hercules engineered a solution. He dug a hole through the foundations of the cattle pen, then an outlet on its other side. Then he diverted the course of the river by damming it. Thus rerouted, the river surged, then gushed through the breech in the stable, washing out its filth with powerful water pressure. A bonus was that the ordure flushed through the stable

\footnotetext{
${ }^{99}$ Charles Singer, 'Some Vesalian Problems', Bulletin of the History of Medicine, 17 (1945), 425-38: 426. See also 427-9, 437-8. Johann Guinther von Andernach, Institutionum anatomicarum secundum Galeni sententiam ad candidatos medicinae libri quatuor (Basel: Balthasar Lasium and Thomas Platter, 1536), 46. Translation mine. For Massa's influence on Harvey, see French, op. cit. (note 20), $22-6$.

100 C. D. O'Malley, Andreas Vesalius of Brussels (Berkeley and Los Angeles, CA: University of California Press, 1964), 90-4, 46, without reference to mehercule.

101 Andreas Vesalius, Anatomicarum Gabrielis Falloppii observationum examen, in Opera omnia anatomica et chirguria, Hermann Baerhaave et al. (eds), 2 vols (Leiden: J. du Vivie and J. and H. Verbeek, 1725), Vol. 2: 794.

102 Harvey, op. cit. (note 1), 20-1.

103 For invention, see Boyle, 'Soliloquy', op. cit. (note 2), and especially its definition on 371.

${ }^{104}$ Harvey, op. cit. (note 1), 21.
} 
fertilised the fields beyond for a bumper crop. But Hercules was refused the promised payment for his labour, a tithe of the oxen. ${ }^{105}$

Hercules' feat has been reduced in modern translation to inventing 'the world's first sewage drain'. ${ }^{106}$ But in Renaissance literature the cleansing of the Augean stable had rich cultural interpretations. Coluccio Salutati's De laboris Herculis reported the invention of dung as fertiliser but allegorised that labour for cleansing the filth of vices. ${ }^{107}$ Hercules' cleaning job was solemnised by a comparison with Christ's death on the cross, which rid the world of the detestable stench of sin. ${ }^{108}$ Erasmus explained the adage 'to cleanse the stable of Augeas' as 'a proverbial allegory, used of a person or thing that is filthy beyond measure'. ${ }^{109}$ In Harvey's time, Leone Allacci, a scriptor at the Vatican Library, exposed an Etruscan forgery as 'a new Augean stable, full of foul odors and outrage... while others gather flowers from the manure, I collect, albeit necessarily, manure'. ${ }^{110}$ It was the secular interpretation of Hercules' labour, about the reform of learning, that Harvey appropriated. Erasmus importantly revived the cleansing of the Augean stable in his youthful manifesto, Antibarbari, to promote the humanist purge of scholasticism, whose 'barbarism' was 'filth'. False friars who regarded themselves as demigods were attacking literary studies. Yet 'if anyone dares to divulge any of their secrets [vices] and disturb the Augean stable, they announce that he is in danger of destruction from an irate Francis, or Dominic, or Elijah, so help me!'. The interlocuter Jacob Batt, a local stand-in for Erasmus's universal labours, recalled how he undertook 'the labours of Hercules' as a schoolmaster:

What an Augean stable I found there. Ye gods! What nonsense, what inanities, what mockery, what barbarism, what thorns and brambles, what dregs had been forced upon the unhappy schoolboys by those before me who had taught them to know nothing.

His pedagogical reforms enraged the citizenry, who accused him of immorality, of heresy, of threatening the end of Christianity and the coming of the Antichrist. He summoned his conversationalists,

You were a witness of that fight; you saw for yourself how I acted Hercules, how many lions and boars and bulls and Stymphalian birds I slew, how many versions of Antaeus or Geryon or Diomedes or Nessus, how I dragged Ceberus out of his den where he was terrifying the pallid shades, and held him up to the

105 Apollodorus 2.5.5; Theocritus, Idylls 25; Pausanias, Descriptio Graeciae 5.1.10. For Theocritus, see Graham Zanker, 'Pictorial Description as a Supplement for Narrative: Augeas' Stable in Heracles Leontophonos', American Journal of Philology, 117 (1996), 411-23; Ivan M. Linforth, 'Theocritus XXV', Transactions of the American Philological Association, 78 (1947), 77-87. See also Pierre Brulé, 'Héraclès et Augé: À propos d'origines rituelles du mythe', in Colette Jourdain-Annequin et al. (eds), IIe recontre Héraclénne: Héraclès: Les femmes et le féminin (Brussels: Institut historique belge de Rome, 1996), 35-49. For the origin of the artistic cycle of his labours, see Bernard Ashmole and Nicholas Yalouris, Olympia: The Sculptures of the Temple of Zeus (London: Phaidon, 1967), 23, 29, pls. 202-11; Frank Brommer, Heracles: The Twelve Labors of the Hero in Ancient Art and Literature, Shirley J. Schwarz (trans. and enlarged) (New Rochelle, NY: Aristide D. Caratzas, 1979), 30.

106 Nigel J. Spivey, Songs on Bronze: The Greek Myths Made Real (New York: Farrar, Strauss and Giroux, 2005), 55.

107 Coluccio Salutati, De laboris Herculis, B.L. Ullman (ed.), 2 vols in 1 (Zurich: In aedibus Thesauri mundi, 1951), 365-7.

108 Jung, op. cit. (note 64), 120. For a Hercules-Christ comparison in 1629, see John Milton's 'Ode on the Morning of Christ's Nativity', cited by Galinsky, op. cit. (note 61), 205.

${ }^{109}$ Erasmus, 'Augeae stabulum repurgare', in Adagia, in J. Clericus (ed.), Opera omnia, 11 vols (Leiden, 1703-6), Vol. 2: 530; (trans.), Collected Works of Erasmus, Vol. 33: 201.

${ }^{110}$ Leone Allacci, Animadversiones in antiquitatum etruscarum fragmenta ab Inghiramo edita (Paris: S. Cramoisy, 1640), 1, 22, cited by Ingrid D. Rowland, The Scarith of Scornello: A Tale of Renaissance Forgery (Chicago, IL: University of Chicago Press, 2004), 74, 75. 
sky; you saw how my Greek fire only just managed to wipe out the Lernaean Hydra, fertile with its own deaths, and I rather think that worst of all plagues is still alive and breathing.... Alone I faced all those monsters, but I did not give way; no, I won through, and convinced the saner intelligences, confuted the others with clear reasoning, and held some up to scorn.

Batt's companions congratulated him as 'Hercules' for his feats and arranged a triumphal procession to honour him. 'We will make you a god, so that you will not be a second Hercules, as the proverb says, but Hercules himself; when did he ever deserve so much' ? ${ }^{111}$

\section{Cleansings}

With his oath mehercule Harvey meant to cleanse the Augean stable of medicine as Erasmus had cleansed that of literature. It was not the first application of that Herculean labour to physiology. Jacobus Sylvius upbraided his former student Vesalius whose $D e$ fabrica dared to slander Galen and by implication him. Sylvius accused Vesalius of violating the Hippocratic Oath of respect to teachers.

This slanderer wickedly renounced his oath of allegiance to his master Hippocrates, in which he had promised the greatest gratitude to his teachers and to their adopted children, and, furthermore, that he sought in every way to criticise them falsely, since he hoped that by competing with such teachers for the leadership in anatomy he might some day acquire reknown.

Sylvius pondered his task of repudiation, reckoning grammar before physiology. 'Everything was so filled with grammatical and other errors, as well as an ignorance of physiology, that it would have been easier to cleanse the Augean stable than to remove even the worst lies from this hodgepodge made up of thefts and bloated with slanders'. ${ }^{112}$

Hercules' cleansing of the Augean stable related to Harvey's invention of the blood's circulation exactly where Harvey swore mehercule. His rhetorical signal was where it classically belonged, in the prooemium, whose synonym was principium, his designation for the status of the heart in the body. Harvey wrote,

That opinion is less tolerable that supposes that, since dual matter (airy and bloody) is necessary for forming the vital spirits, it contends that the blood sweats across through the invisible porosities in the drudge of the heart from the right into the left ventricle, and air is drawn through the great vessel, the arterial vein; and accordingly that in the septum of the heart there are very many porosities for admitting the blood. But, by Hercules, there are no porosities, nor can they be demonstrated. ${ }^{113}$

The argument repudiated Galen's notion that the cardiac ventricles were separated by a porous septum. Through its minute invisible holes the finest particles of the venous blood supposedly passed from the right to the left ventricle for purification. Renaissance anatomists agreed and marvelled, or wondered and doubted. Matteo Realdo Columbo, Vesalius's successor at Padua, argued in De re anatomica against the porosity of the interventricular septum. He rerouted the blood flow from the right ventricle of the heart through the pulmonary artery to the lungs, then from there to the left ventricle of the heart

\footnotetext{
${ }^{111}$ Erasmus, op. cit. (note 90), Vol. 2: 101. Erasmus, Antibarbari, Kasimierz Kumaniecki (ed.), in Opera omnia (Amsterdam), Vol. 1-1: 74-5, 59-60, 62-3; Mann Phillips (trans.), op. cit. (note 96), Vol. 23: 49, 25, 36-7.

112 Jacobus Sylvius, Vesani cujusdam calumniarum in Hippocratis Galenique rem anatomicam depulsio (Paris, 1551), fols. 4r, 28r, cited by O'Malley, op. cit. (note 100), 248, 250, without reference to my argument. For Vesalius's impiety, see French, op. cit. (note 20), 36-8. For Vesalius's praise of Sylvius, see his De fabrica, 3r.

113 Harvey, op. cit. (note 1), 18.
} 
through the pulmonary vein. ${ }^{114}$ Harvey's proem, which swore by Hercules against Galen's porous septum, acknowledged Columbo's 'opinion'. ${ }^{115}$ Neither acknowledged Miguel Servet's speculation about his theology of the soul in Restitutio christianismi against the septum and for a transfer of the blood through the lungs. ${ }^{116}$

A medical septum was a membranous separator. ${ }^{117}$ An ordinary septum was any 'fence, enclosure, wall', but particularly a 'cattle-fold', or enclosure for livestock. ${ }^{118}$ Harvey knew both senses, for the word appeared in Vergil's Eclogues, which he cited on the title page of his Prelectiones. ${ }^{119}$ In that poem, the enslaved shepherd Tityus abandoned the 'folds' (saepta) to travel to Rome as a freedman. ${ }^{120}$ For Harvey, the cardiac septum was like a cattle-fold that he would cleanse by abandoning it. Since in Galen's anatomy the septum admitted the blood through it, Harvey had to divert that flow. To cleanse the Augean stable of medicine, Harvey dammed the septum, which allegedly sweat, seeped, or trickled blood across the heart through undemonstrated porosities. By vivisection and dissection, he had been unable to observe any such openings. As he emphatically swore, 'by Hercules, there are no porosities, nor can they be demonstrated'. He concluded his refutation of the septum with the necessity of opening an alternative route. Diverting the blood flow from the septum, he channelled it continuously through the arteries and veins. Harvey argued that circulation was consistent with the pulse of the heart and arteries, with the transfusion of blood from the veins into the arteries, and with their distribution of the blood throughout the body. ${ }^{121}$ Harvey knew about the use of rivers to clean stables on an explicitly circular model, for Padua, where he studied medicine, was a round city encircled by rivers. ${ }^{122}$ Fynes Moryson, an English tourist in 1591-5, recorded the course of Alpine rivers. 'These Rivers enter the City, and with divers channels drive many mils, compasse the wals, and not onely make the fields fertile, but serve to carry all commodities (abounding here) from hence to Venice, and to bring from thence such things as they want...' He ended with a Herculean task '.. . and besides doe cleanse all filth of the stables and privies' ${ }^{123}$

Harvey's circulation further imitated Hercules' successful dependence on the rushing force of the water flow to cleanse the Augean stable. That efficacy Harvey applied de copia sanguinis. ${ }^{124}$ Although honoured as his 'quantitative argument', ${ }^{125}$ Harvey wrote

114 C.R.S. Harris, The Heart and the Vascular System in Ancient Greek Medicine: From Alcmaeon to Galen (Oxford: Clarendon, 1973), 305, 313-14, 322, 333, 334; Walter Pagel, William Harvey's Biological Ideas: Selected Aspects and Historical Background (Basel: S. Karger, 1967), 129-30, 134, 156-69.

115 Harvey, op. cit. (note 1), 12, for Matteo Realdo Columbo, De re anatomica (Venice: N. Bevilaqua, 1559).

116 Miguel Servet, Restitutio christianismi (Vienne, 1553).

117 Celsus, De medicina 4.1.4; (trans.), Vol. 1:357; cf. 7.4.2. See also Jacques André, La vocabulaire latin de l'anatomie (Paris: Belles lettres, 1991), 139.

118 Columella, Res rustica 4.1 .

119 Vergil, Eclogae 3.60, cited by Harvey, op. cit. (note 44), 2.

${ }^{120}$ Vergil, Eclogae 1.34.

121 Harvey, op. cit. (note 1), 18, 32.

${ }^{122}$ For contemporary English travelogues, see Thomas Coryat, Coryat's Crudites, 2 vols (Glasgow: James Maclehose and Sons for the University, 1905), Vol. 1: 270; Fynes Moryson, An Itinerary, 3 vols (Glasgow: James Maclehose and Sons, 1907), Vol. 1: 150. See also Vicenzo Dotto's map, Pianta di Padova, in Angelo Portenari, Della felicità di Padova (Padua: Tozzi, 1623). For Harvey and Paduan waterways, see also Boyle, 'Harvey in the Sluice', op. cit. (note 2).

123 Moryson, ibid., 152.

${ }^{124}$ Harvey, op. cit. (note 1), 32, 41.

125 See e.g. French, op. cit. (note 20), 90-3, 106, 372; Pagel, op. cit. (note 113), 24-5, 73-9; Pagel, 'William Harvey Revisited (I) and (II)', History of Science, 9 (1970), 1; Don G. Bates, 'Harvey's Account of His "Discovery”, Medical History, 36 (1992), 361-78, with copia as 'large amount', 363. 
quantitas, paralleled with proportio, only once. He emphasised copia in two chapter titles and repeated it twenty-one times more. ${ }^{126}$ The primary lexical meaning of copia is not quantity but 'abundant power'. Harvey borrowed his chapter titles, De copia sanguinis, from the textbook of exercises in style at the King's School. As its royal charter prescribed, 'Finally, in the sixth form they essay those formulas De copia verborum et rerum written by Erasmus and learn to vary rhetoric in numerous ways, so that they might thus attain a faculty in the Latin language (as much as is sufficient for boys)'. ${ }^{127}$ Human speech, Erasmus began suggestively, 'is a magnificent and impressive thing when it surges along like a golden river, with thoughts and words pouring out in rich abundance'. He advised recourse to literary passages where 'the spring of eloquence seems to bubble up particularly richly'. That concept of copia, 'powers of expression', did not denote quantity, although some amount was necessarily connoted. It was a 'godlike power of speech' distinct from the 'excessive verbosity' of 'mere glibness'. Students were warned against sheer quantity - not to 'pile up a meaningless heap of words and expressions without any discrimination'. Although copia drew from a store of language and material, that treasury was to be commanded judiciously and elegantly for appropriateness to the subject and audience. In fact, brevity might be required, but again not in consideration of quantity - not 'to say as little as possible, but to say the best things as briefly as possible'. Erasmus forbade 'excessively long digressions at inappropriate points'. He counselled 'due account of order and arrangement lest a mass of unorganised material throw the whole speech into confusion and disorder'. In studying De copia, Harvey learned not how to count but how to develop resourcefulness and judgement. ${ }^{128}$ What he paralleled with De copia sanguinis was 'blood supply'. Although he observed the blood supply as plentiful (quanta copia), his emphasis was not its measured amount but its ready availability. Harvey's copia intended function, 'blood supply' for a useful and appropriate purpose. In traditional physiology, blood was concocted in and consumed by the body in a terminal process that required renewal. Harvey's observation, during numerous dissections, of the blood spurting liberally suggested another possibility. 'I, I began to think to myself whether it might have some movement as if in a circle, which afterwards I found out to be true'. ${ }^{129}$

From that intuition to its proof, Hercules' feat of hydraulic engineering to cleanse the Augean stable was a model for the rhetorical disposition of Harvey's labours. He argued for the circulation of the blood, as his proem with the Herculean oath stated, by 'ocular demonstrations' and 'reasoned arguments', ${ }^{130}$ that is by comparative anatomy and natural philosophy. But he presented his achievement to his colleagues by adopting the Herculean medical persona, and that was a rhetorical imitation that personified those labours. His was not a generic role, as in Wolfgang Höfer's Hercules medicus, which will illustrate and praise every physician as clubbing the Hydra of diseases. ${ }^{131}$ Harvey's particular labour was the cleansing of the Augean stables, an excellent comparison. The damming of the water/blood flow for diversion into a new channel and the efficacy of its powerful supply accomplished the deed for the first and second Hercules.

\footnotetext{
126 Harvey, op. cit. (note 1), 41, 43, 44, 45, 46, 47, 48, 50, 52, 53, 54, 63, 72. For quantitas, see 44.

${ }^{127}$ Leach, op. cit. (note 9), 468.

128 Erasmus, op. cit. (note 44), 34, 26, 34, 28, 26, 35-8, 280; (trans.), 303, 295, 303, 298, 295, 658.

129 Harvey, op. cit. (note 1), 41.

${ }^{130}$ Harvey, op. cit. (note 1), 5, 58.

${ }^{131}$ Wolfgang Höfer, Hercules medicus; sive, locorum communum liber (Venice: Jacobus Kürner, 1657), frontispiece and preface.
} 
Initially tossing to and fro mentally to understand cardiac movement, Harvey compared himself to Aristotle, for whom 'the motion of heart was like the flux and reflux of Euripus' ${ }^{132}$ Harvey repeated the anecdote from the physician André DuLaurens, ${ }^{133}$ whose late scholasticism relied on the authority and reasoning that perpetuated such ignorance. ${ }^{134}$ But the medical subtext was Galen's De usu partium, which rejected the comparison of the blood flow to the tidal flow in the straits of Euripus. ${ }^{135}$ The classical source for the anecdote about Aristotle was Procopius's history, which recorded how the phenomena of currents in straits 'appear to be susceptible of no explanation, nor has anyone ever shewn himself able to account for them'. As Procopius foretold the issue of authority that confronted Harvey in the College,

I am aware that as a general thing all men, if they first discover an ancient argument, are no longer willing to devote themselves to the labour involved in the search for truth nor to learn instead some later theory about the matter in hand, but the more ancient view always seems to them sound and worthy of honour, while contemporary opinions are considered negligible and are classed as absurd.

\section{Euripus was a vexing example of a universal problem. 'Indeed', Procopius continued,}

it was this question which led Aristotle of Stagira, a man prominent among all others to go to Chalcis on Euboea, where he observed the strait which they call Euripus in an effort to discover by careful investigation the physical reason why it is and in what manner it comes about that sometimes the current of the strait flows from the west, but at other times from the east.

Sailors navigated by the temporary direction of the current, reversing course as required by the tidal inflow and outflow. 'All this the Stagirite observed and pondered for a long time, until he worried himself to death with anxious thought and so reached the term of his life'. ${ }^{136}$

The tidal phenomenon of Euripus was well publicised, from Strabo's geography, to Pliny's natural history, to Boethius's philosophy. ${ }^{137}$ For contemporary English readers, Nathanael Carpenter's Geography recounted the ebb and flow of the sea as

\footnotetext{
132 Harvey, op. cit. (note 1), 20. This comparison is not in Aristotle's extant works, although he cites Euripus for earthquakes and the purple murex in Meterorologia 366a; Historia animalium 547a.

133 Harvey, op. cit. (note 1), 20, citing André DuLaurens, Historia anatomia humani corporis, in Opera omnia anatomica et medica (Frankfurt: William Fitzer, 1627), 352. If Harvey consulted this edition, it would date his sentence, and it may have motivated the submission of his own manuscript to that publisher.

134 Jerome J. Bylebyl, 'Disputation and Description in the Renaissance Pulse Controversy', in op. cit. (note 88), 226-7, 241-2.

135 Galen, De usu partium libri XVII, George Helmreich (ed.), 2 vols (Amsterdam: A. M. Hakkert, 1968), Vol. 1: 331. Cf. De methodo medendi, in Opera, Vol. 10: 649, 697. George Ent's Apologia pro circuitione sanguinis (Leiden: Peter Vander, 1687), which was dedicated to Harvey, included a formal digression on 'the ebb and flow of the sea', 64-100.

136 Procopius, History of the Wars of Justinian 8.6.20, 10; Procopius, H.B. Dewing (trans.), 7 vols (Cambridge, MA: Harvard University Press, 1962-71), Vol. 5: 107, 103-5, 107-9.

${ }^{137}$ Pliny, Naturalis historia 2.99.218-2.100.219; Strabo, Geographia 1.2.30; Boethius, De consolatione philosophiae 2.1 meter. Cf. the tidal phenomenon of the straits of Gibralter with the Pillars of Hercules, which the hero erected as his monument. Diodorus Siculus, Bibliotheca 4.18.4-5; Procopius, Historia 8.6.3, 8.6.8; Thomas Heywood, The Brazen Age (London: Nicholas Okes for Samuel Rand, 1613), 38, 42. See also the title page of Bacon, Instauratio magna, 1620, and A.D. Burnett, The Engraved Title-Page of Bacon's 'Instauratio magna': An Icon and Paradigm of Science and its Wider Implications (Durham: Thomas Harriot Seminar, 1998), 2 figure 1, and 6-11. For Bacon and Harvey, see also Keynes, op. cit. (note 14), 157-61, 433; French, op. cit. (note 20), 325-7. Cf. also the mouth of the Thames River, a native analogy that Harvey later explicates, inserting himself into the tradition of Aristotle's deliberation about Euripus with that English example. Ercole V. Ferrario and F.N.L. Poynter, 'William Harvey's Debate with Casper Hofmann on the Circulation of the Blood: New Documentary Evidence', Journal of the History of Medicine and Allied Sciences, 15 (1960), 15-21: 15. Hofmann seems not to have known that the Thames is a tidal river, which regularly reverses its flow. 'Caspar Hofmann
} 
one of the greatest difficulties in Naturall Philosophie: insomuch as Aristotle one of the acutest of Philosophers, is reported to haue stood amazed at the flowing and ebbing of Euripus, and despairing of finding out the cause, at length enforced to cast himself into the River which had before confounded him. ${ }^{138}$

Even after Harvey's days at Cambridge, a student's notebook recorded the rhetorical question 'Did Aristotle drown himself in Euripus', and his terse reply, 'I do not think our Prince was so insane'. ${ }^{139}$ The anecdote was topical to praise scientific discovery that surpassed traditional natural philosophy. Francesco Stelluti, a member of the Accademia dei Lincei, introduced his colleague Galileo Galilei's Il Saggiatore with this praise:

\author{
once an ancient sought the cause, \\ Near to Chalcis so men tell, \\ Why Euripus' wave no pause \\ Made in ebb and flow as tides now rose and fell; \\ Had you told him what so well \\ You have proved of your belief \\ He would not have plunged into those waves from grief. ${ }^{140}$
}

By citing the Euripean topic, Harvey pleaded his case for his solution of Aristotle's worry as deserving of fame.

Harvey early learned that tidal phenomenon from Erasmus's resourceful De copia. A technique of expressing a superlative varied a noun with a comparative, such as 'more restless than Euripus'. In his textbook of similes, Parabolae, its ebb and flow typified inconsistent persons. His great compilation of Adagia repeated the saying 'Man's a Euripus' for changeable persons and fortunes. ${ }^{141}$ Euripus fit the change of mind Harvey pressed on his colleagues to stabilise his challenged appointment as their lecturer in anatomy. Euripus also presaged his task of Herculean heroism. In Seneca's drama Hercules Oetaeus a dying Hercules sacrificed himself to Jupiter on a cliff above the straits of Euripus and there won immortality. ${ }^{142}$ Erasmus recalled it in his textbook on letter writing as an example of philosophical mysteries cloaked in legend. The moral of Hercules' immolation above Euripus was that 'immortality was only the lot of those who had spent their whole life in honourable labours and unquenchable ardour for virtue, and had waged war tirelessly upon the monstrous apparition of all vices'. ${ }^{143}$ Thomas

to William Harvey', Appendix I in Gweneth Whitteridge, William Harvey and the Circulation of the Blood (London: Macdonald, 1971), 242. For Hofmann, see French, op. cit. (note 20), 255-8.

138 Nathanael Carpenter, Geography Delineated Forth in Two Books, 2nd edn (Oxford: John Lichfield and William Turner for Henry Cripps, 1625), book 2, 82.

${ }^{139}$ Cited by William T. Costello, The Scholastic Curriculum at Early Seventeenth-Century Cambridge (Cambridge, MA: Harvard University Press, 1958), 59.

${ }^{140}$ Francesco Stelluti, 'Al detto Sig. Galilei del sig. Francesco Stelluti, Accademico Linceo', in Galileo Galilei, Antonio Favoro et al. (eds), Le opere di Galileo Galilei, reprint of Edizione Nazionale, 20 vols (Florence: S.A.G. Barbèra, 1929-39), Vol. 6: 209; The Controversy on the Comets of 1618, Stillman Drake et al. (trans.), (Philadelphia, PA: University of Pennsylvania Press, 1960), 159.

${ }^{141}$ Erasmus, op. cit. (note 44), 104; translation mine. Erasmus, Parabolae, Betty I. Knott (ed.), in Opera omnia (Amsterdam), Vol. 1-5: 272. Erasmus, 'Euripus homo', in op. cit. (note 31), Vol. 2-2: 382-5; (trans.), Collected Works of Erasmus, Vol. 32: 215-6.

142 Seneca, Hercules Oetaeus lines 774-841. For the heart and blood, see lines 1220-3; for the pillars of Hercules, line 1240.

${ }^{143}$ Erasmus, De conscribendis epistolis, Jean-Claude Margolin (ed.), in Opera omnia (Amsterdam), Vol. 1-2: 337; Charles Fantazzi (trans.), Collected Works of Erasmus, Vol. 24: 88. 
Heywood's The Brazen Age dramatised it for English audiences: how with his 'flesh frying with poyson' Hercules wished to plunge into the cooling straits of Euripus. ${ }^{144}$

Mentally in such straits, Harvey wrote that the problem of the heart's movement 'fluctuated' to him with 'contrary, various, and confused' indications, like the reversing ebb and flow at Euripus. ${ }^{145}$ That echoed his professor at Padua, Girolamo Fabrici d'Aquapendente, on the 'perpetual flux and reflux of the blood'. ${ }^{146}$ Fabrici had cut an incision in a vein to explore its wickets (ostiola), 'some exceedingly slender tiny membranes in the internal hollow of the veins'. He decided that the membranes regulated the blood flow, which he abandoned in the feet. ${ }^{147}$ It was at that fork in the anatomical path that Harvey made the topical choice of Hercules. Erasmus's De copia had further taught him 'Prodicus' invention about Hercules debating whether he should enter on the steep uphill path of virtue, or the downhill path of pleasure'. The choice of Hercules between divergent routes Y, a Renaissance convention for moral decision, ${ }^{148}$ Harvey converted to physiology. Like Hercules at the crossroads, he chose the right, upward path and reasoned that the blood flowed from the foot of the hill/body back upward.

The venous wickets also reminded Fabrici of 'knots in the fine shoots of plants'. He illustrated his simile by juxtaposed engravings of a ligated arm with the venous wickets and a branch of the herb verbena having similar knots at its sprouts. ${ }^{149}$ Botanical knots were granted since antiquity to Hercules as his principal attribute, the knotty club cut from a branch. It figured in Seneca's drama about his immolation unto immortality on the cliff above the straits of Euripus. ${ }^{150}$ Hercules' knotty club loomed colossally in Padua. He had already figured in the foundation of that noble city, as Angelo Portenari related in Della felicita di Padova, by descendents from a son or companion. ${ }^{151}$ The famed Renaissance sculptor and architect Bartolomeo Ammannati carved Hercules Bestiarius from eight blocks of local stone and erected the statue in the courtyard of Marco Mantua Benavides, a jurist at the university. Visible through a triumphal arch and above the walls, the colossus stood twenty-five feet high. The surfaces of an octagonal plinth of five feet more depicted in bas relief Hercules' seven feats of slaying beasts and his symbolic apotheosis. On the hero's club Ammannati carved his own name. ${ }^{152}$

\footnotetext{
${ }^{144}$ Heywood, op. cit. (note 135), 34-42, with citation 39. See also Shakespeare, Antony and Cleopatra IV.xii.43-7.

145 Harvey, op. cit. (note 1), 20.

${ }^{146}$ Ibid. Cf. Girolamo Fabrici d'Aquapendente, De venarum ostiolis (Padua, 1603), facsimile reprint, Kenneth J. Franklin (ed.) (London: Balliére, Tindall, and Cox, 1933), 72.

${ }^{147}$ Franklin, ibid., 72, 71, 75, 78, 80-1.

148 Erasmus, op. cit. (note 44), 208; trans., 282. The source is Xenophon, Memorabilia 2.1.21-34; but also Cicero, De officiis 1.32.118. See Erwin Panofsky, Hercules am Scheidewege und andere antike Bildstoffe in der neuren Kunst (Leipzig: B.G. Teubner, 1930); Waith, op. cit. (note 18), 42-4; Emma Stafford, 'Vice or Virtue? Herakles and the Art of Allegory', in Louis Rawlings et al. (eds), Herakles and Hercules: Exploring a GraceoRoman Divinity (Swansea: The Classical Press of Wales, 2005), 71-96.

${ }^{149}$ Fabrici, op. cit. (note 144), 75, 78, 80-1.

150 Seneca, Hercules Oetaeus line 1661.

151 Portenari, op. cit. (note 120), 10, 11, 12.

152 Corrado Lattanzi, 'L'attività giovanile de Bartlomeo Ammannati in Veneto', in Niccolò Rosselli Del Turco et al. (eds), Bartolommeo Ammanati scultore e architteto, 1511-1592 (Florence: Associazione dimore historiche italiane, Sezione Toscana: Alinea, 1995), 88-93; Michael Kiene, Bartolomeo Ammannati (Milan: Electa, 1995), 34-45; Lionello Puppi, 'Il "Colosso" del Mantova', in Sergio Bertelli et al. (eds), Essays Presented to Myron Gilmore, 2 vols. (Florence: La Nuova Italia, 1978): Vol. 1: 11-29; Joachim Poeschke, Michelangelo and His World: Sculpture of the Italian Renaissance, Russell Stockman (trans.) (New York: Harry N. Abrams, 1996), 195-206.
} 
The untying of knots, such as the plant-like nodes of Fabrici's venous membranes, was conventional for the solution of riddles or puzzles. Hercules legendarily invented a knot that was difficult or impossible to undo, hence the proverbial 'Herculean knot' for an insolvable problem. ${ }^{153}$ The Herculean, or square, knot also had a medical application, reported in Pliny's Naturalis historia as a special power to heal the wounds it bound. Oribasius's collection of medical texts included Heraklas's description of Greek surgical knots, with instructions on how to tightly tie the Hercules knot. ${ }^{154}$ Harvey was required in his first year as lecturer at the College to lecture surgeons biweekly on Oribasius's text, ${ }^{155}$ so he knew and perhaps demonstrated Hercules' knot. For Harvey, cardiac movement was such a problem that it initially seemed 'almost known to God alone'. ${ }^{156}$ Harvey's resolution of its operation thus elevated him to quasi divine status, like the immortality Hercules won for his deeds. Medical divinisation was not arrogant but topical. Erasmus's declamation on medicine rehearsed its cliches, how medical discoverers were revered as gods, like their founder, Asclepiades, who was equated with the honours of Hercules. As Erasmus emphasised, 'If immortality is something which is to be desired, then it is achieved as far as is humanly possible by medical research, which can prolong life almost indefinitely'. ${ }^{157}$ Immortality was more commonly achieved through progeny, however, and Harvey acknowledged that reality in his lecture on the genitals as 'the string tied to eternity'. ${ }^{158}$ By sexual acts of procreation, the species continued, and the individual lived on, as it were, through successive generations. But William Harvey and his wife, Elizabeth, were childless. ${ }^{159}$ His only chance for the progeny that ensured immortality was through the popular topic of the book as a child. ${ }^{160}$ A colleague Martin Llewelyn in 1653 prefaced a translation of Harvey's Disputations concerning the Generation of Animals with a poem praising his books as issues of his brain although his loins had none. ${ }^{161}$ The History of the Worthies of England will posthumously award Harvey his children by naming his

153 Erasmus, 'Herculanus nodus', in op. cit. (note 81), Vol. 2-2: 367-8; 'nodum solvere', Vol. 2-1: 28, 118-19. For the knot of virginity (hymen) on the London stage, see Ben Johnson, 'Hymnaei; or, the Solemnities of Masque and Barrier at a Marriage', in Stephen Orgel (ed.), Selected Masques (New Haven, CT: Yale University Press, 1970), 49, 342; William Shakespeare and George Willis, Pericles IV.ii.1146, cf. Shakespeare, The Tempest IV.i.16. See also Stephanos Panayotakis, 'The Knot and the Hymen: A Reconsideration of nodus virginitatis (Hist. Apoll. 1)', Mnemosyne, 53 (2000), 605, 603. See also Ann M. Nicgorski, 'The Magic Knot of Herakles: the Propaganda of Alexander the Great, and Tomb II at Vegina', in Rawlings et al. (eds), op. cit. (note 146), 97-102.

154 C. L. Day, Quipus and Witches Knots: The Role of the Knot in Primitive and Ancient Cultures (Lawrence, KS: University of Kansas Press, 1967), 53-7, citing Pliny, Naturalis historia 28.17.63-4. For Oribasius in translation, De laqueis, see 117-18. For illustrations, see 133, 138, 144.

155 Whitteridge, op. cit. (note 135), 83.

156 Harvey, op. cit. (note 1), 20. Cf. DuLaurens, op. cit. (note 131), 352.

${ }^{157}$ Erasmus, Declamatio in laudem artis medicae, J. Domański (ed.), in Opera omnia (Amsterdam), Vol. 1-4: 164-6, 167, 168, 178-80, 184, 185-6; Brian McGregor (trans.), Collected Works of Erasmus, Vol. 29: 39, 45, $47-8,49,42$.

158 Harvey, op. cit. (note 44), 175.

${ }^{159}$ Keynes, op. cit. (note 14), vii, 47.

${ }^{160}$ Ernst R. Curtius, European Literature and the Latin Middle Ages, Willard R. Trask (trans.) (London: Routledge and Kegan Paul, 1953), 132-3.

161 Elizabeth Spieler, Science, Reading, and Renaissance Literature (Cambridge: Cambridge University Press, 2004), 71-2. 
books. 'The Doctor, though living a bachelor, may be said to have left three hopeful sons to posterity'. 162

The Hippocratic Oath that physicians swore not only aspired to the practicality of a good reputation but also prayed for the glory of an eternal fame. ${ }^{163}$ Erasmus's De copia taught young Will how to swear for immortality in the best Latin style. For variation, it transformed a declaration into an oath. 'Nothing do I hold more dear or more to be preferred than glory' became 'I'll be damned if I honour anything more than glory' ${ }^{164}$ The College of Physicians belatedly acknowledged Harvey's 'labours' by carving Hercules' epithet 'immortal' on his statue. ${ }^{165}$ An observer John Collop, MD, poetised 'On Doctor Harvey' and his Herculean labours, praising his cleansing of the Augean stable of medicine:

Non datur ultra Hercules pillars show,

Beyond a Hercules labours thou dost go.

Sev'n headed Hydra, error multiply'd

Thou need'st no Club, thy knife can soon divide:

Augean filths no work when vy'd with thee,

Do'st cleanse the Jakes of all antiquite.... ${ }^{166}$

162 Thomas Fuller, History of the Worthies of England (London, J. G. W. L. and W. G. for Thomas Williams, 1662), cited by H. Bayon, 'William Harvey, Physician and Biologist: His Precursors, Opponents, and Successors', Annals of Science, 3 (1938), 59-118: 85.

163 Edelstein, op. cit. (note 39), 51-2.

164 Erasmus, op. cit. (note 44), 76; trans., 347. For cursing, see Edelstein, op. cit. (note 39), 157-8.

165 Keynes, op. cit. (note 14), 290, 316, 420, 397.

166 John Collop, 'On Doctor Harvey', in Poesis Redivia; or, Poesies Reviv'd, in Conrad Hilberry (ed.), The Poems of John Collop (Madison, WI: University of Wisconsin Press, 1962), 102. 